\title{
Provision of Classroom Environment for Students with Hearing Impairment: Case Study of a Special School in Karachi City
}

\author{
Dr. Saira Saleem \\ Assistant Professor, Department of Special Education, University of Karachi \\ Address: Department of Special Education, Sheikh Zayed Islamic Center, University Road, University of \\ Karachi, Karachi-75270 \\ Prof. Dr. Shahida Sajjad \\ Dean Faculty of Social Sciences, Malir University of Science \& Technology, Karachi \\ Address: A-12, Block 4, Gulistan E Jauhar, Karachi - 75290 \\ Dr. S Khurram Khan Alwi \\ Associate Professor, Department of Humanities, Greenwich University \\ Address: Greenwich University, Dk $1038^{\text {th }}$ St, D.H.A Phase 6 Darakhshan villas, Karachi-75500
}

\begin{abstract}
This quantitative case study was conducted at a special school in Karachi city to find out the provision of classroom environment for students with hearing impairment. The data collected through a checklist was analyzed through descriptive statistics and One-Sample Test. The study concluded that the teachers consider the special needs of their students while organizing classroom environment for their students with hearing impairment. Most of them were using multi-sensory resources and learning equipment but there was a lack of provision of instructional area in classroom for different activities that is why majority of the teachers always teach whole class at a time and never provide group activities either in form of small groups or in pair of students. Although mostly the classes have rows of desk for students with hearing impairment but sometimes the teachers could manage to allow students to work alone.
\end{abstract}

Keywords: Classroom environment, students with hearing impairment, special school.

DOI: $10.7176 / \mathrm{PPAR} / 9-5-04$

Publication date:May $31^{\text {st }} 2019$

\section{Introduction}

Classroom environment constitute various activities including; curriculum planning, organizing classroom, provision of learning equipment and resources, instructional methods, proper lightening in classroom, managing acoustic condition, grouping students in classroom and seating arrangement of students to facilitate effective teaching and learning to achieve the goals of education. Among the ten Professional Standards developed for initial preparation of teachers in Pakistan, standard 6 also highlight learning environment for social interaction, motivation and learning in classroom (Government of Pakistan, 2009). Many research studies highlight the importance of learning and teaching environment (Farooqi, Akhtar, \& Nadeem, 2013; Khan, Chandio, \& Farooqi, 2014; Tagliacollo, Volpato, \& Pereira Junior, 2010) not only from students' achievement perspectives but also to measure performance of teachers. Little is known about how teachers and students deal with the school and classroom environment for their teaching and learning (Stadler-Altmann, 2013) and it can be very difficult to find the perfect way to manage a classroom (Sajjad, 2008). The present case study was designed to investigate the classroom environment provided by teachers for students with hearing impairment at ABC Special School in Karachi.

\section{Literature Review}

Having a disability can be one of the most marginalizing factors in a child's life and schools face many challenges to meet special education needs of children with disabilities (Bulat, Hayes, Macon, Tichá, \& Abery, 2017). The students with hearing impairment have special education needs arise due to their disability in hearing. They rely mostly on vision to learn so teacher need to consider light reflection in the classroom, place seats in a circle or semicircle form, (AmpliVox, 2014) which allows students to interact with each other.

In a class of students with hearing-impairment, it is very much appropriate to have 8 to 10 students and due to small number of students, the seating arrangement can be made more suitable to their needs and the classroom space can be utilized in a better way for the purpose of individual and group activities. The semi-circular arrangement of the desk helps to make an eye contact of teacher and student for the purpose of communication and discipline management and teacher can be in touch with each student easily and quickly as the teacher can move freely. The smaller distance between the teacher and student can also make speech reading and listening through hearing aid easily while a distance of more than 6 feet would make speech reading \& listening difficult. 
The small low table and chair of teacher make it easier for all students to read the teacher's face at the same level as themselves. If the students are wearing hearing aids, voice at the same level has better directional flow towards the microphone than a voice directed from above their heads passing over the microphone \& wasting teaching opportunity.

In classroom the teacher's chair, work table \& blackboard need to be facing the light source i.e. placed opposite to the window. The light on the teacher's face helps the student to coordinate sound and vision to understand the teacher's words (language) and to see her facial expressions. While talking to the student the teacher should be seated instead of walking. This gives full view of face \& body language to student who have language, focusing $\&$ attention problems. Whilst keeping eye contact control. If the teacher walks the deaf child cannot lip read the teacher due to changing direction \& moving in and out of light and shade. The hearings aids also can't cope sound always varying in distance (therefore volume) \& direction as the teacher walks about. The two tables at the back of classroom can be utilized for practical work in-group with full concentration and according to the abilities of students with hearing impairment. If the classroom space is not enough, to put these extra tables then the tables and chairs can be rearranged for group activity when the teacher so desires. The use of assistive technology is also very helpful for students with hearing impairment. These can be purchased locally and need not to be expensive. High-tech assistive technologies include; hearing aids, alternative communication devise. Examples of low-tech assistive technologies include; visual aids, magnifying glass, audio books, tape recorder, large print and adaptive learning material.

\section{Research Method}

The present research was a case study carried out in a special school of Karachi which was selected through purposive sampling having students with hearing impairment. The sample of study constituted 25 teachers selected through purposive sampling method, including 20 female teachers and 05 male teachers. Most of the teachers were less than 30 years old and qualification wise mostly were having a master's degree in special education. The dependent variables included all teachers of special school selected for case study and the independent variables included; classroom environment organization, classroom seating arrangement and grouping of students with hearing impairment in special schools selected for case study. The data was collected through a checklist to find out that how teachers were organizing classroom environment for students with hearing impairment at ABC Special School in Karachi. The instrument was designed based on literature review and a research conducted in the field of special education (Bano \& Aziz, 2012) and consisted of 13 items. The responses were collected on three point scale; "Always", "Sometime" and "Never'. The Cronbach Alpha value of the instrument as indicated in table 1 is 0.701 which shows that the instrument was reliable and the results can be generalized on same population. The data was collected with the help of a checklist by personally visiting the special school and taking interview of teachers. The process of data collection took a period of almost one months. Descriptive statistics was used for data analysis through SPSS version 23 and hypotheses were tested through One Sample Test at 0.05 level of significance.

Table 1. Reliability Statistics

\begin{tabular}{ll}
\hline \multicolumn{2}{c}{ Reliability Statistics } \\
\hline Cronbach's Alpha & N of Items \\
.701 & 13 \\
\hline
\end{tabular}

\section{Results And Findings}

The study was based on three research questions and three hypotheses were formulated based on research questions.

Research question 1: How do teachers organize classroom environment for students with hearing impairment at ABC Special School in Karachi?

The classroom environment organized by teachers for students with hearing impairment included the provision of; multi-sensory resources, learning equipment, instructional areas to perform different activities, proper lightening in classroom, and sound controlled classroom (table 2),

Table 2. Teaching Environment

\begin{tabular}{lcccc}
\hline \multicolumn{1}{c}{ Responses } & $\begin{array}{c}\text { Always } \\
\mathrm{N} \%\end{array}$ & $\begin{array}{c}\text { Sometimes } \\
\mathrm{N} \%\end{array}$ & $\begin{array}{c}\text { Never } \\
\mathrm{N} \%\end{array}$ & Total \% \\
\hline $\begin{array}{l}\text { Availability of multi-sensory resources } \\
\text { Use of learning equipment }\end{array}$ & $20(40 \%)$ & $12(24 \%)$ & $18(36 \%)$ & $50(100)$ \\
& $22(44 \%)$ & $18(36 \%)$ & $10(20 \%)$ & $50(100)$ \\
$\begin{array}{l}\text { instructional areas provided in the } \\
\text { classroom for different activities }\end{array}$ & $16(32 \%)$ & $10(20 \%)$ & $24(48 \%)$ & $50(100)$ \\
$\begin{array}{l}\text { Proper lightening in classroom } \\
\text { Sound controlled classroom }\end{array}$ & $28(56 \%)$ & $17(34 \%)$ & $05(10 \%)$ & $50(100)$ \\
\hline
\end{tabular}


Table 2 displays that overall, majority of teachers always $(40 \%)$ provide multisensory resources to their students with hearing impairment, majority of the teachers (44\%) always use learning equipment during their teaching, but majority of teachers (48\%) never provide instructional area in classroom for different activities. Majority of the teachers (56\%) have proper lightening in classroom and majority of the teachers $(40 \%)$ have sound controlled classrooms.

Research hypothesis 1 (H1): There was no significant difference among the opinion of teachers about their provision of classroom environment for students with hearing impairment at ABC Special School in Karachi.

This hypothesis was tested by One-Sample Test and the results are given below in table 3 .

Table 3. Opinion of teachers about their provision of classroom environment for students with hearing impairment.

\section{One-Sample Statistics}

\begin{tabular}{|c|c|c|c|c|c|}
\hline \multirow{2}{*}{\multicolumn{2}{|c|}{$\mathrm{H} 1$}} & \multirow[t]{2}{*}{$\mathrm{N}$} & \multicolumn{2}{|c|}{ Std. Deviation } & td. Error Mean \\
\hline & & & 3.66723 & & \\
\hline \multicolumn{6}{|c|}{ One-Sample Test } \\
\hline & \multirow[t]{2}{*}{$\mathrm{t}$} & \multirow[t]{2}{*}{ df } & \multirow[t]{2}{*}{ Mean Difference } & $95 \%$ Con & al of the Difference \\
\hline & & & & Lower & Upper \\
\hline H1 & 17.392 & 49 & 9.02000 & 7.9778 & 10.0622 \\
\hline
\end{tabular}

Table 3 shows that the sig value was less than 0.05 therefore it is concluded that there was no significant difference among the opinion of teachers about their provision of classroom environment for students with hearing impairment at ABC Special School in Karachi.

Research question 2: What type of the classroom seating arrangement was provided to students with hearing impairment by their teachers at ABC Special School in Karachi?

The type of the classroom seating arrangement was reflected through the arrangements of desks in rows, arranging small groups of 3-8 students, and having both rows of desks and small group at the same time in classroom (table 4).

Table 4. Classroom seating arrangement

\begin{tabular}{|c|c|c|c|c|}
\hline Responses & $\begin{array}{c}\text { Always } \\
\text { N \% }\end{array}$ & $\begin{array}{c}\text { Sometimes } \\
\mathrm{N} \%\end{array}$ & $\begin{array}{c}\text { Never } \\
\mathrm{N} \%\end{array}$ & $\begin{array}{c}\text { Total } \\
\%\end{array}$ \\
\hline Rows of desks & $36(72)$ & $4(8)$ & $10(20)$ & $50(100)$ \\
\hline Small groups of $3-8$ students & $10(20)$ & $12(24)$ & $28(56)$ & $50(100)$ \\
\hline Both rows of desks and small group at the same time & $12(24)$ & $4(8)$ & $34(68)$ & $50(100)$ \\
\hline
\end{tabular}

Table 4 shows that majority of teachers (72\%) always have rows of desks, majority of teachers (56\%) never arrange students in small groups in class, and majority of teachers $(68 \%)$ never have both rows of desks and small group at the same time. So, majority of teachers (72\%) always have rows of desk in their room deigned for students with special needs.

Research hypothesis 2 (H2): There was no significant difference among the opinion of teachers about provision of type of the classroom seating arrangement for students with hearing impairment at ABC Special School in Karachi.

This hypothesis was tested by One-Sample Test and the results are given below in table 5 .

Table 5. Opinion of teachers about the provision of type of the classroom seating arrangement for students with hearing impairment.

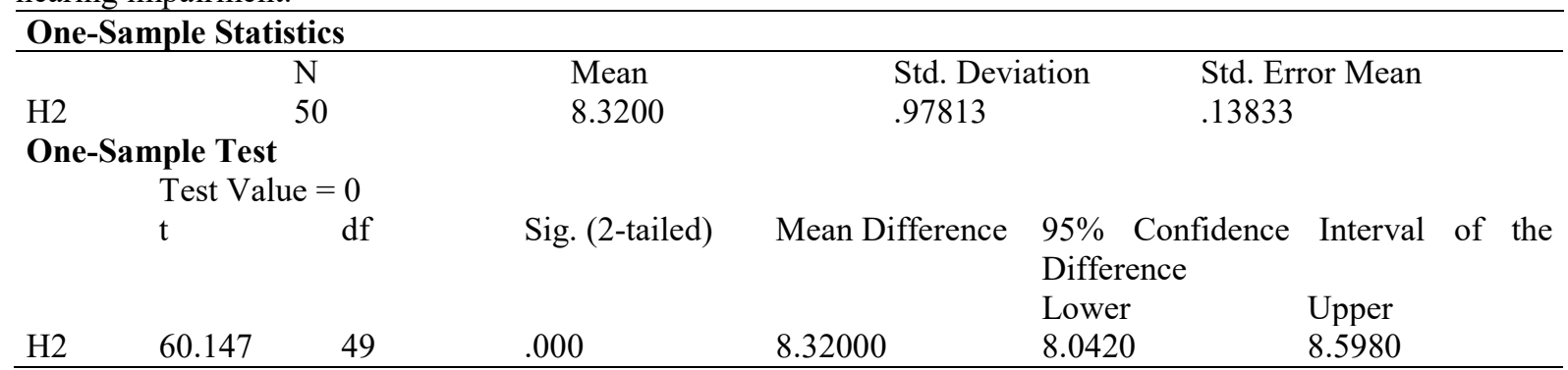

Table 5 shows that the sig value was less than 0.05 therefore it is concluded that there was no significant difference among the opinion of teachers about provision of type of the classroom seating arrangement for students with hearing impairment at ABC Special School in Karachi.

Research question 3: How teachers were grouping students with hearing impairment in classroom at $\mathrm{ABC}$ Special School in Karachi (table 6)

Table 6 reflects students' grouping by teachers in the form of; making several small groups (3-8 students), pairs ( 2 students), student work alone, and one large group/whole class. 
Table 6. Students' Grouping

\begin{tabular}{lllll}
\hline Responses & Always & Sometimes & Never & Total \% \\
& N \% & N \% & N \% & \\
\hline Several small groups (3-8 students) & $12(24)$ & $8(16)$ & $30(60)$ & $50(100)$ \\
Pairs (2 students) & $12(24)$ & $12(24)$ & $26(72)$ & $50(100)$ \\
Student work alone & $10(20)$ & $12(24)$ & $28(56)$ & $50(100)$ \\
One large group/ Whole class & $40(80)$ & $4(8)$ & $6(12)$ & $50(100)$ \\
\hline
\end{tabular}

Table 6 shows that majority of the teachers $(60 \%)$ never make several small groups in class, majority of the teachers $(72 \%)$ never make pair in class, and majority of the teachers $(56 \%)$ never allow their student to work alone and majority of the teachers $(80 \%)$ always teach whole class at a time.

Research hypothesis 3 (H3): There was no significant difference among the opinion of teachers about the grouping of students in classroom arrangement for students with hearing impairment at ABC Special School in Karachi.

This hypothesis was tested by One-Sample Test and the results are given below in table 7 .

Table 7: Opinion of teachers about the grouping of students in classroom

\begin{tabular}{|c|c|c|c|c|c|c|}
\hline \multicolumn{7}{|c|}{ One-Sample Statistics } \\
\hline & & $\mathrm{N}$ & Mean & Std. Deviation & Std. Error Mean & \\
\hline H3 & & 50 & 6.2800 & .78350 & .11080 & \\
\hline \multicolumn{7}{|c|}{ One-Sample Test } \\
\hline & $\mathrm{t}$ & $\mathrm{df}$ & Sig. (2-tailed) & Mean Difference & $\begin{array}{l}95 \% \text { Confidence } \\
\text { Difference }\end{array}$ & Interval of the \\
\hline H3 & 56.677 & 49 & .000 & 6.28000 & $\begin{array}{l}\text { Lower } \\
6.0573 \\
\end{array}$ & $\begin{array}{l}\text { Upper } \\
6.5027\end{array}$ \\
\hline
\end{tabular}

Table 7 shows that the sig value was less than 0.05 therefore there was no significant difference among the opinion of teachers about the grouping of students in classroom arrangement for students with hearing impairment at ABC Special School in Karachi.

\section{Discussion}

Both beginner and experienced teachers consider classroom management to be a high priority and an area of concern (Sokal, Smith, \& Mowat, 2003).The present study revealed that majority of teachers organize their classrooms by frequently using multi-sensory resources and learning equipment to their students with hearing impairment during their teaching.

Physical environment of classroom can influence students' learning and behavior e.g., seating arrangements, lighting, and organization, can influence students' behavior and attention to academic tasks (Fullerton \& Guardino, 2010; \& Guardino \& Fullerton, 2010). Appropriate lighting is also necessary for those students who supplement audition with speech reading (Kaderavek \& Pakulski, 2002). For students with hearing impairment, visual or auditory distractions, poor lighting, obstruction of line of sight, and seating near doors or windows with high traffic are among the classroom features that can influence academic engagement (Dye \& Bavelier, 2010) and the best seating arrangement for students with a hearing loss is one that is consistent and presents minimal distractions (Dye, Hauser, \& Bavelier, 2006). Acoustics and noise are also important factors that teachers need to consider in teaching and learning of students with hearing impairment because noisy learning environment affects students' ability to understand teachers, focus on their work (Choi \& McPherson, 2005; Robinshaw, 2007; Sorkin, 2000), and focus on the lesson presented by the teacher or on peer discussion (Crandell \& Smaldino, 2000). The present study illustrates that majority of the teachers have proper lightening in classroom and have sound controlled classrooms.

Teachers generally manipulate the environment for their students in changing the arrangements of desks and chairs to improve their teaching and the students' learning.( Stadler-Altmann, 2015) but the teachers lack ideas about change in classroom settings to improve their teaching (Martin, 2002). The present study also highlighted the lack of provision of instructional area in classroom for different activities that is why majority of teachers always teach whole class at a time and never provide group activities either in form of small groups or in the form of pairing students and the students always work alone. Mostly the classrooms have rows of desk for students and this traditional arrangement is very effective if the teacher is using chalkboard and projector. The results are in line with findings by Higgins, Hall,Wall, Woolner, and McCaughey (2005) who concluded that presence of traditional classrooms with rows allows more interaction between teacher and students by free movement of teacher in classroom. McLeod, (2003) also noted room arrangement with space allowing teacher for an easy movement to monitor student's improvement. As pointed out by Müller (2008), the teacher's movement can produce interaction with and between the students to motivate students. A study conducted by Guardino and Anita (2012) showed a functional relationship between the physical environment of classroom and 
both an increase in levels of academic engagement and a decrease in levels of disruptive behavior of students with hearing impairment.

\section{Conclusion}

The classroom organization was evident as the teachers consider the special needs of their students with hearing impairment and were using multi-sensory resources and learning equipment but there was a lack of provision of instructional area in classroom for different activities that is why majority of teachers always teach whole class at a time and never provide group activities either in form of small groups or in pair of students. Although mostly the classes have rows of desk for students with hearing impairment but sometimes the teachers could manage to allow students to work alone.

\section{References}

AmpliVox. (2014). Classroom layouts: Seating arrangements for effective learning. Retrieved from http://blog. ampli.com/2014/03/classroom-layouts-seatingarrangements-for-effective-learning.html.

Bano, U., \& Aziz, H. (2012). Teaching styles of special education teachers at College level. Pakistan Journal of Special Education, 13, 151-162.

Bulat, B., Hayes, A. M., Macon, W., Tichá, R., \& Abery, B. H. (2017). School and Classroom Disabilities Inclusion Guide for Low- and Middle-Income Countries. RTI Press Publication No. OP-0031-1701. Research Triangle Park, NC: RTI Press. Retrieved from http://doi.org/10.3768/rtipress.2017. op.0031.1701

Choi, Y. C., \& McPherson, B. (2005). Noise levels in Hong Kong primary schools: Implications for classroom listening. International Journal of Disability, Development, and Education, 52, 345-360.

Crandell, C. \& Smaldino, J. (2000). Classroom acoustics for student with normal hearing and with hearing impairment. Language, Speech and Hearing Services in the Schools, 31, 362-370.

Dye M. W. G. Bavelier D. (2010). Differential development of visual attention skills in school-age student. Vision Research 50, 452-459. doi:10.1016/ j.visres.2009.10.010.

Dye, M. W., Hauser, P. C. \& Bavelier, D., (2006). Do deaf individuals see better? Trends in Cognitive Sciences, 10 , 512-528. doi:10.1016/j.tics.2006.09.006.

Deaf TEC. (2015). Best practices for teaching (ClassACT). Retrieved from http://deaftec.org/classact

Farooqi, M.T.K., Akhtar, M. M.S., \& Nadeem, M. (2013). Development and Validation of Performance Appraisal Scale (PAS-SSTS) for Secondary School Teachers. J. Asian Dev. Stud, 2(4), 88-97.

Ferris State University. (2015). Teaching strategies for hearing impaired students. Retrieved from http://ferris. $\mathrm{edu} / \mathrm{htmls} /$ colleges/university/disability/faculty-staff/ classroom-issues/hearing/hearing-strategy.htm

Fullerton E. K.\& Guardino C. (2010). Teacher and students' perceptions of a modified inclusion classroom environment. Electronic Journal for Inclusive Education. Retrieved from http://www.cehs.wright.edu/resources/publications/ejie/WinterSpring2010

Government of Pakistan (2009). National professional Standards for Teachers in Pakistan. Islamabad: Policy and Planning Wing, Ministry of Education, Government of Pakistan.

Guardino, C \& Anita, D. S. (2012). Modifying the Classroom Environment to Increase Engagement and Decrease Disruption with Students Who Are Deaf or Hard of Hearing. The Journal of Deaf Studies and Deaf Education, 17(4), 518-533.

Guardino, C. \& Fullerton, E. K. (2010). Changing behaviors by changing the environment: A case study of an inclusion classroom. Teaching Exceptional Student, 42, 8-13.

Higgins, S., Hall, E., Wall, K., Woolner, P. and McCaughey, C. (2005) The Impact of School Environments: A Literature Review, London: Design Council.

Kaderavek, J. N. \& Pakulski, L. A. (2002). Minimal hearing loss is not minimal Teaching. Exceptional Student, $34,14-18$.

Khan, H.M.A; Chandio, J.H; \& Farooqi, M.T.K. (2014). Comparison of Performance Appraisal System in Public and Private Schools. Pakistan Journal of Commerce and Social Sciences, 8 (1), 272-278.

Martin, S.H. (2002) 'The classroom environment and its effects on the practice of teachers', Journal of Environmental Psychology, 22,139-156.

Müller, W. (2008) 'Der Lehrer auf der Bühne des Klassenraums. Wirkungen der Raumregie' [Teacher on Stage of the Classroom. Effects of the Stage Directions], Pädagogik, 60: 26-30.

Sajjad, S. (2007). Teacher as Classroom Manager. SCHEMA, Annual Journal of Humanities and Social Sciences, (4), 151-168.

Stadler-Altmann, U. (2015). Learning environment: The influence of school and classroom space on education. In The Routledge International Handbook of Social Psychology of the Classroom. Rubie-Davies, C; Stephens, J.M., \& Watson, P. Routledge. (Eds, pp.p. 252-262.

Tagliacollo, V. A., Volpato, G. L. and Pereira Junior, A. (2010). Association of student position in classroom and school performance. Educational Research, 1, 198-201. 